\title{
Papers
}

\section{Communicating culture: An examination of the buying behaviour of 'tweenage' girls and the key societal communicating factors influencing the buying process of fashion clothing}

Received (in revised form): 6th October, 2005

\section{Isabel J. Grant}

is a graduate of the University of Aberdeen and has worked as a lecturer at the University of Staffordshire and Aberdeen College, prior to taking up a senior lecturer's post at The Robert Gordon University, Aberdeen. She is head of the Marketing Department within the Aberdeen Business School and is also course leader for the MSc in International Marketing Management. She teaches at both postgraduate and undergraduate level, both in the university and abroad. Her research interests are international marketing and branding.

\section{Graeme R. Stephen}

is a graduate of Nottingham Trent University and has worked in the media for some 20 years prior to taking up his lecturing post at The Robert Gordon University, Aberdeen. Graeme is the course leader for the Aberdeen Business School's BA Honours Management Programme. He teaches postgraduate and undergraduate students as well as to external corporations. His research interests include branding and buying behaviour.

Isabel J. Grant

Aberdeen Business School,

The Robert Gordon

University, Aberdeen, UK

Tel: +44 1224263019 and 263840;

Fax: +44 1224 263838; e-mail: i.grant@rgu.ac.uk

Abstract This paper examines younger teenage ('tweenage') girls' purchasing decisions for fashion clothing and the impact of brands on their behaviour. This group is highly fashion-sensitive. The study utilises purely qualitative methods to explore the role of branding and purchasing influences from the perspective of these young people in order to gain a richer and deeper understanding of their behaviour. The findings, based on four focus groups, show that the key decision factors when buying are parental and peer group approval, together with the fact that purchasing of fashion items is strongly influenced by the brand name and its associations. Further, the findings revealed that the respondents were prepared to pay a premium for a branded product and placed a high emphasis on the product being deemed 'cool'. The findings provide the basis for further research into older children's and their parents' buying behaviour. In particular, future research will seek to examine the influence of such issues on the complete purchasing process, from problem recognition to post-purchase evaluation in order to ascertain whether age and experience change the buying process and perceptions.

\section{INTRODUCTION}

The term 'tweenagers' is relatively new in marketing terminology, but has captured the attention and interest of marketers and many commercial stakeholders in different fields of business, who are, or are 
becoming, aware of the huge potential of this group. 'Tweens' are those young people whose ages range from 'pre-adolescent to 14 years' and have been described as 'the richest generation' in history. It has also been said that the spending of this age group 'has roughly doubled every ten years over the last three decades'. ${ }^{1}$

Although the term 'tweenagers' has been adopted in marketing terminology, there exists a considerable variation as to the specific age band for these young people. Teenagers are those young people aged between 13 and 19 years, although Datamonitor ${ }^{2}$ describes them as being between 14-19 years old, and it is on this latter group as a whole that the majority of published work has been written.

Tweenagers are at the younger end of this age spectrum and comprise those between 11 and 13 years of age according to Datamonitor, ${ }^{2}$ and between 10 and 14 years of age according to Mintel, ${ }^{3}$ while Clarke $^{4}$ classifies them as 8-12-year-olds. Teenagers as a whole have long been recognised as a target group for manufacturers, but it is this new group of tweenagers which has emerged as a key focus for many fashion retailers.

The 'tween demographic is a rich target. Tweens are leaving the kids' line a little younger at about the time when mom stops buying the items for them and they start buying on their own'. ${ }^{5}$ Tween marketing can be a sensitive area. Emotionally and intellectually, these young people have some way to go in their development. Marketers must not make the mistake of creating language or visuals that may be deemed as patronising, however, since 'fitting in and being cool' is of utmost concern to tweenagers. ${ }^{6}$ Marketers have to ensure that their products and services are perceived by such a target market as being a 'cool' brand. The consumer power of young people is growing in importance. As a market, tweenagers are increasingly directing the spending of their parents as well as themselves, and for marketers are a future market in themselves. ${ }^{7}$ The tweenage market has become more significant as these young people copy the behaviour of older teenagers, by demanding their own fashion brands in an attempt to demonstrate their own sophistication. The growth in this market has arisen from distinct social trends couples are having fewer children later in life, have established career paths and have more discretionary income to spend on their offspring. 'Furthermore, with increasing divorce levels and rising numbers of households in which both parents work full-time, the "guilt factor" is leading many to indulge tweens' well-publicised passion for designer clothes'. ${ }^{8}$ Young people therefore have enormous potential for marketers as a current market, as an influence market as well as a future market, and it should also be noted that it is during adolescence that consumers often develop loyal buying patterns that continue with time throughout their adult lives. ${ }^{9}$ It has been identified that 'manufacturers are becoming more blatant in their efforts to target children, as traditional taboos on advertising directly to the child are being eroded'. ${ }^{10}$

\section{THE ECONOMIC POWER OF THE TEENAGE/TWEENAGE MARKET}

Today's teenagers have more money and 'wield more economic clout than their predecessors'. ${ }^{11}$ Various surveys ${ }^{12-14}$ have been carried out to try to determine how much money is available to this group. It has been estimated that 'the total annual spending power for UK children (7-16-year-olds) will exceed over $\mathcal{E}^{3} \mathrm{bn}$ in 2006 , rising from $\mathcal{E}^{2.7 \mathrm{bn}}$ in 2002'. ${ }^{15}$ Another survey indicated that 'Britain's 9 million plus children (aged 
5-16 inclusive) have a total weekly spending power of approx. $\mathcal{E}^{6} 60 \mathrm{~m}$ '. ${ }^{16}$ The average spend per month on clothes by both sexes is 31.70 , with the top brands being Adidas, Nike, Top Shop, Tammy Girl and New Look. Girls are more interested in style and will hunt for "cheaper versions of the "right" designer clothes'. ${ }^{17}$ 'Girls are particularly likely to spend their money on clothing and shoes, with 24 per cent of girls having made a purchase of such items in the last year'. ${ }^{18}$ Recent research indicates that tweenagers are 'the group with the fastest-rising spending power on the High Street'. ${ }^{19}$ This group therefore represents a growing and substantial market segment, but while literature exists on younger children and the influences on their behaviour, little academic research has been published on what influences tweens' buying of fashion clothing in particular.

\section{THE TEENAGE CLOTHESWEAR MARKET}

'Most children's clothing is aimed at 3-14-year-olds, with the highest demand coming from the highly

fashion-conscious 9-14-year-olds or tweenagers. The main market growth is from the fashion conscious 10-14-year-olds, which has benefited sales of designer clothing, especially for girls'. ${ }^{20}$ These girls are not only very aware of fashion trends, but have money to spend and are also very much influenced by pop celebrities and sports personalities in what they purchase. ${ }^{21}$

The total UK market value for children's wear in 2001 was $£ 5,570 \mathrm{~m}$; girls' clothing dominated the market by

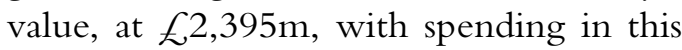
sector forecast to increase. ${ }^{22}$ Two of the major changes that have taken place over the past decade in this market are the increasing awareness of brands and the increasing exposure to fashion from a relatively young age among this segment. 'The girlswear market has shown the strongest level of growth within childrenswear, outpacing boyswear and infantswear, because of an increased interest in fashionability and a trend towards disposable fashions in the girlswear market. Growth in the market has been spearheaded by a rise in spend by the 'tweenies', a very important age group of 10-14-year-olds, for whom rapidly changing fashions have played a major role'. ${ }^{23}$

\section{CONSUMER BEHAVIOUR AND CONSUMER SOCIALISATION}

Consumer behaviour is a complex area, but marketers do need to try to find out as much as they can about who their customers are in order to identify their needs, how they behave, what influences them to make a decision to buy and what processes they follow when selecting a product/service. This information is required so that marketers can target their marketing activities as precisely and cost effectively as possible. There are many influences on purchasing behaviour, including social (culture, sub-culture, social class, reference groups, family), technological, political, economic and personal factors (motivation, personality, self-image, perception, learning, beliefs and attitudes), not all of which will be discussed or included in this paper. The main thrust of the literature review will centre on attitudes, brands, family, peer group and consumer socialisation.

An attitude has been defined as 'an overall favourable or unfavourable evaluation of a product or service'. ${ }^{24}$ Attitudes are basically people's likes and dislikes regarding products, services, ideas, brands, organisations and people. Attitudes are learned through the socialisation and 
cognitive processes and can therefore be changed. They act as a framework on which we build thoughts and beliefs. However, changing attitudes can be difficult, as they fit into a pattern, and to change one attitude may require radical adjustments to be made to others. ${ }^{25}$

A consumer's attitude to a brand is very influential in the decision-making process, and attitudes are shaped by many factors, including education, economic circumstances, family, age, experience, the law and social background. ${ }^{26,27}$

'Of all environmental socialisation agents, parental influence is the most pervasive and important. The response of parents to children's attempts at influencing family purchases acts as reinforcements to children's future behaviour as consumers'. ${ }^{28}$ 'The family can be regarded as the primary source (agent) of consumer socialisation and it is a particularly important reference group to take into account in the decision-making process'. ${ }^{29}$

Reference groups consist of people who share common beliefs and values and with whom we have regular direct contact, and can be classified as either primary or secondary; both are important, as they influence buying behaviour. A reference group has been defined as 'a group of people that an individual refers to for comparison when making judgments about his or her own circumstances, attitudes and behaviour'. ${ }^{30}$ Family and friends therefore fall into this category, as they are important influencers of behaviour, through their social communication activities. 'For tweenagers, the brand is king, and the ferocity of the peer community and the overwhelming compulsion to be accepted by their peers has driven a strong sense of brand kinship for this demographic' ${ }^{31}$

It has been argued that parental socialisation helps children develop habits and values which are congruent with the prevailing cultural environment. ${ }^{32}$ Parents directly influence their children through discussions, and indirectly through modelling 'consumption behaviour'. ${ }^{33,34}$ “"Tweenagers" (8-12-year-olds) ... on the whole have a good relationship with their parents'. ${ }^{35}$

Children, as they grow and learn, are exposed to many different influences on their behaviour, and a wealth of information has been gathered over the years regarding children's knowledge about the marketplace as consumers. ${ }^{36}$ Consumer socialisation of children is an area which has been well researched ${ }^{37}$ and has been defined as 'processes by which young people acquire skills, knowledge and attitudes relevant to their functioning as consumers in the market-place'. ${ }^{38}$ It has been stated that 'Much consumer behaviour is performed under the influence of others. The very foundation of human behaviour is learning from others', ${ }^{39}$ while a more recent academic states that 'consumer socialisation is a function of, inter alia, the age of the child, the content that is learned and agents of socialisation'. ${ }^{40}$

One of the best known frameworks on child development has been described as 'genetic epistemology'. ${ }^{41}$ This academic proposed that there are four primary cognitive structures or developmental stages — sensorimotor, pre-operations, concrete operations and formal operational. The latter stage, (formal operational, 11 years and over) is the stage that is most pertinent to the present research. At this point, children can think logically about abstract propositions and test hypotheses systematically. They also become concerned with the hypothetical, the future and ideological problems. ${ }^{42}$ As children grow and mature, there take place 'dramatic developments in cognitive functioning and social 
Table 1: Consumer socialisation stages

\begin{tabular}{|c|c|c|c|}
\hline $\begin{array}{l}\text { Characteristic } \\
\text { years }\end{array}$ & $\begin{array}{l}\text { Perceptual stage } \\
\text { (3-7 years) }\end{array}$ & $\begin{array}{l}\text { Analytical stage } \\
\text { (7-11 years) }\end{array}$ & $\begin{array}{l}\text { Reflective stage } \\
\text { (11-16 years) }\end{array}$ \\
\hline \multicolumn{4}{|c|}{ Knowledge structures } \\
\hline Orientation & Concrete & Abstract & Abstract \\
\hline Focus & Perceptual features & Functional/underlying features & Functional/underlying features \\
\hline Complexity & $\begin{array}{l}\text { Unidimensional } \\
\text { Simple }\end{array}$ & $\begin{array}{l}\text { Two or more dimensions } \\
\text { Contingent ('if-then') }\end{array}$ & $\begin{array}{l}\text { Multidimensional } \\
\text { Contingent ('if-then') }\end{array}$ \\
\hline Perspective & $\begin{array}{l}\text { Egocentric } \\
\text { (own perspective) }\end{array}$ & $\begin{array}{l}\text { Dual perspectives } \\
\text { (own }+ \text { others) }\end{array}$ & $\begin{array}{l}\text { Dual perspectives in social } \\
\text { context }\end{array}$ \\
\hline \multicolumn{4}{|c|}{ Decision-making and influence strategies } \\
\hline Orientation & Expedient & Thoughtful & Strategic \\
\hline \multirow[t]{2}{*}{ Focus } & Perceptual features & Functional/underlying features & Functional/underlying features \\
\hline & Salient features & Relevant features & Relevant features \\
\hline \multirow[t]{2}{*}{ Complexity } & Single attributes & Two or more attributes & Multiple attributes \\
\hline & $\begin{array}{l}\text { Limited repertoire of } \\
\text { strategies }\end{array}$ & $\begin{array}{l}\text { Expanded repertoire of } \\
\text { strategies }\end{array}$ & $\begin{array}{l}\text { Compete repertoire } \\
\text { of strategies }\end{array}$ \\
\hline Adaptivity & Emerging & Moderate & Fully developed \\
\hline Perspective & Egocentric & Dual perspectives & $\begin{array}{l}\text { Dual perspectives in social } \\
\text { context }\end{array}$ \\
\hline
\end{tabular}

Source: John (1999) ${ }^{36}$

maturation'. ${ }^{43}$ 'Age related improvements in cognitive abilities contribute to the development of consumer knowledge and decision-making skills. ${ }^{, 4}$ John $(1999)^{36}$ created the consumer socialisation stages shown in Table 1.

The reflective stage of this matrix, the most appropriate to this study, is the final stage in the child's socialisation process. As children become more aware of their role as consumers, so their knowledge about the commercial marketplace and fundamental concepts such as pricing and branding becomes more sophisticated.

'Many of these changes are more a matter of degree than kind. More distinct is the shift in orientation to a more reflective way of thinking and reasoning, as children move into adolescence and become more focused on the social meanings and underpinnings of the consumer marketplace. A heightened awareness of other people's perspectives, along with a need to shape their own identity and conform to group expectations, results in more attention to the social aspects of being a consumer, making choices and consuming brands. ${ }^{45}$

During this stage too, 'adolescents" knowledge about branding becomes extremely important. Acceptance by the peer group is often guaranteed when a teenager wears the 'right' brand of T-shirt or jeans'. ${ }^{46}$ 'Peers play an enormous role when teenagers have to make buying decisions in this early adolescent stage'. ${ }^{47}$

Table 2 provides a useful topic summary of previous research findings, which are applicable to the reflective stage of the four groups interviewed in this study.

\section{BRANDS}

One of the major platforms for any company is branding its products and/or services. 'Brands are at the very heart of marketing. When a company creates a strong brand it attracts customer preference and builds a defensive wall against competition'. ${ }^{48}$ A brand promises the consumer value and quality. A successful brand must communicate a distinct advantage to the consumer and the more that it delivers what it promises, the greater will be the word of mouth recommendation from satisfied consumers to others. 'Brands encapsulate a whole range of communication, 
Table 2: Topic summary of previous research findings

\begin{tabular}{|c|c|}
\hline Topic & Reflective stage (11-16 years) \\
\hline Advertising knowledge & Sceptical attitudes towards advertisements \\
\hline \multirow[t]{2}{*}{ Decision strategies } & Use multiple attributes \\
\hline & Full repertoire of strategies \\
\hline \multirow[t]{2}{*}{ Product and brand knowledge } & $\begin{array}{l}\text { Substantial brand awareness for adult-orientated as well as child-relevant } \\
\text { product categories }\end{array}$ \\
\hline & Understanding and enthusiasm for retail stores \\
\hline Information search & Gather information on functional, perceptual and social aspects \\
\hline Product evaluation & $\begin{array}{l}\text { Focus on important attribute information: functional, perceptual and social } \\
\text { aspects }\end{array}$ \\
\hline
\end{tabular}

Source: Adapted from John (1999) ${ }^{36}$

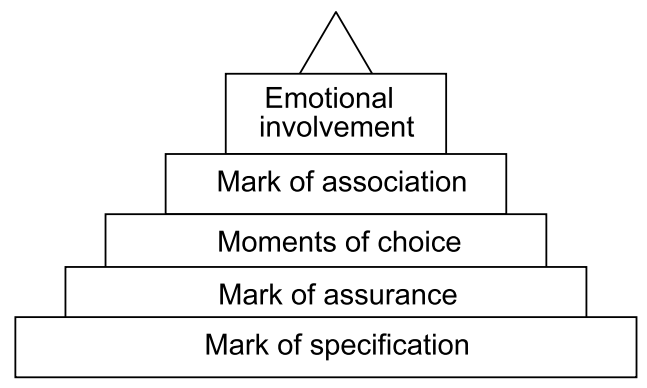

Source: dobney.com

Figure 1: The brand pyramid

learning, history, feeling about a product or company within a simple name and logo'. ${ }^{49}$ Furthermore, 'The concept of a brand can be thought of as a pyramid consisting of different layers of meaning and involvement'. ${ }^{50}$

Figure 1 illustrates the brand pyramid. At the lowest level, a brand is simply an identifying mark to distinguish the product from alternatives; there is an implicit statement of specification. At the next level, the brand becomes a mark of assurance. Moving up another step, the brand starts to represent moments of choice. At the next step, the brand provides a mark of association, a badge of a club that the individual wants to be associated with. Here, the purchaser is starting to make some form of emotional connection with the brand and to use the brand to establish a self-image to other people. The final stage is when the brand starts to represent who the individual wants to be, 'The brand is me. This is my brand'. ${ }^{2}$
Many marketing companies have followed the strategy that exposure to brands from an early age brings about long-term brand loyalty and have therefore adopted a cradle to grave strategy. Branding must also be a continuous and consistent process. Companies recognise the value of having strong brands in their portfolio, as this helps build a loyal customer base. Branding exists primarily for identification and to smooth the task of differentiating products. ${ }^{52}$

However, evidence would seem to point to the fact that 'tweens are an audience that has shown no particular brand loyalty, ${ }^{53}$ and that indeed they fear commitment - where, then, does that leave the marketer? Brands, it would appear, are in a fairly risky position - if a young person adopts a particular brand and becomes committed to it, they may be stuck with an old-fashioned image and little flexibility to change. If, on the other hand, a tween is slow to adopt, 
they may be seen as 'weak and a weak reputation will leave them isolated and conspicuously alone'. ${ }^{54}$

Another important influence on this age group's behaviour is the role model. A role model can be anyone with whom the individual adolescent comes in contact, either directly or indirectly, who may have an influence on their decisions or behaviour. ${ }^{55}$ Such a definition permits 'a variety of individuals to be considered role models, including parents, siblings, peers, teachers, entertainers and athletes'. ${ }^{56}$ 'The music, showbusiness or athletics star represent something of an ideal ... and for the teenager, there is the desire to be like his or her hero. As a result the response to role models in terms of consumption is manifest in clothes, make-up, music, art and even language'. ${ }^{57}$ 'Teenagers are more involved with trends than probably any other age group. They are not only trend-setters for one another, but are also trend-setters for the population at large' ${ }^{58}$ Celebrities and other role models therefore have a major impact on purchasing behaviour. 'For tween girls, design and style are the most important aspects of fashion with many aspiring to fashions worn by media icons, like Victoria Beckham'. ${ }^{59}$ "Some of the top reasons that make a brand a "cool brand" are: "quality", "it's for people my age", "advertising”, "if cool friends or peers use it", and "if a cool celebrity uses it". ${ }^{60}$

Current literature on the tweenage market leaves several questions unanswered about this group as consumers, such as:

- How influenced are tweenagers by brands in their buying of clothes? (This is the main focus of the present research.)

- Are tweenagers influenced by what they read, hear or see about fashion clothing?
- Do their attitudes change, once they have assimilated this information?

- Do their purchasing decisions alter as a consequence of acquiring new information?

\section{METHODOLOGY}

The research, in the controlled environment of a business school, made the participants feel 'relaxed and unthreatened ${ }^{\prime 61}$ and took the form of four, one-hour long, structured focus group interviews. Each interview consisted of six tweenage girls, aged between 12 and 14 years, who attended two different state schools, in the same catchment area of the city. A total of 39 open-ended questions were formulated to identify what influences tweenage girls when buying fashion clothing. These questions were subsequently broken down into the following five related themes, which form the basis of the findings: (1) influences, (2) buying behaviour, (3) information gathering, (4) brand awareness and (5) expectations of the brand.

As this was a small convenience sample, it was not appropriate to apply statistical techniques to the results; instead, content analysis techniques ${ }^{62}$ were employed to answer the research questions. The responses were analysed by grouping them into the above themes and drawing conclusions, which formed the basis of the results presented. This involved bringing the different subjects together with the two researchers. The group interview method was favoured, with an approach which enabled researchers to explore a research question, or identify key information sources, and whereby the interaction between the group members would stimulate their reflection on the problem put before them. ${ }^{63}$

The results are presented in the Interview Results and Discussion section and 
are related to the consumer socialisation stages - reflective stage, $11-16$ years. ${ }^{64}$

The research involved the utilisation of qualitative methods, and the main objective was to establish the respondents' attitudes to buying fashion clothes and to their friends' and family's influences on their behaviour. The focus groups were selected in order to provide a greater, in-depth understanding of the young people's behaviour and views on the research area. The animators - often referred to as 'moderators' - gained from the ability to capture 'the richness and fullness associated with qualitative data'. ${ }^{65}$

The focus group technique was chosen as the medium for gathering information, as it enables the explicit use of group interaction to produce insights that would be less accessible without the interaction found in a group. ${ }^{66}$ In addition, 'focus groups allow for participant focus over researcher emphasis'. ${ }^{67,68}$ The focus group approach is a means of emphasising "empathy and commonality' of experiences and in addition it encourages 'self-disclosure and self-validation'. A focus group has several advantages, including speed, flexibility, assessment of attitudes and group interaction, as well as providing information on new topics, allowing the moderators to gain valuable information on behaviour and language, and also providing useful perceptual information prior to any subsequent development of the research. ${ }^{69,70}$

As stated, the authors attempted to investigate the buying process, the main influencing factors and the attitudes of young tweenage girls to buying fashion clothing, and tried to ascertain how the respondents buy and the role that parents and friends play in the process. At the outset, the moderators were cognisant of the age group of the children interviewed $^{71}$ and the importance of gaining their approval, as well as that of their parents, prior to conducting the focus group interview. The girls in the focus groups attended two separate schools in the same city, and selection for inclusion in the groups was determined by a number of factors. As previous research has identified, ${ }^{72}$ subjects can become reticent about opening up in front of other participants; the researchers therefore chose girls who already knew one another. Both authors had relatively easy access to girls in this age group, as opposed to boys. In addition, when approached to take part in the focus group interview, there was no resistance to doing so either on the part of the parents or the girls. Indeed, the tweenage girls were unanimously in favour of assisting in an area of research in which they had a general interest. It was decided, therefore, to confine the research to tweenage girls on this occasion and draw comparisons with boys' behaviour in the same age group in future research.

The research was a team approach, with one moderator asking the open-ended questions, the responses being taped, while the other moderator observed and took additional notes, reflecting outward behaviour, interest and general perceptual cues reflected in the participants. The authors systematically reflected on their role in the enquiry. They were sensitive to their personal biography and were cognisant of how this shapes the study. ${ }^{73}$ Both have siblings in this age group and were acutely aware of the need to maintain objectivity throughout. This 'personal-self represents an 'honesty and openness to research, acknowledging that all enquiry is laden with values' ${ }^{74}$

Major functions of the selected methodology were to 'help the blind man see', ${ }^{75}$ in this case, the two researchers, and to facilitate the 
communication between the two researchers, who wanted to share a common experience. ${ }^{76}$

A pilot of the semi-structured open-ended questions enabled the authors to develop relevant lines of questions, as well as providing some conceptual design for the research. ${ }^{77}$ Four focus groups of female tweenagers, aged 12-13 years, then took place.

Propositions were developed ${ }^{78,79}$ which were taken to the focus group for discussion. The questions posed were 'themed' into the five research areas, (influences, buying behaviour, information gathering, brand awareness and expectations of the brand), recorded and subsequently transcribed for content analysis.

The research design was interpretative. ${ }^{80-82}$ Particular emphasis was placed on the examination of personal observations and interviews within the focus group. ${ }^{83}$ Interpretations were confirmed and supported by the transcription of the multiple respondents. ${ }^{84}$ Each respondent's comments were cross-analysed to highlight similarities and differences from the questions posed. During the interview process, the girls were asked to clarify what they understood by key terms such as 'branded clothing' and 'brand image' prior to asking them to describe the context of such terms through the questions asked. ${ }^{85}$

Little by way of instrumentation was employed - the authors were essentially the main measurement device in the study, bearing in mind the sensitivity of the people in this age group. The analysis was completed with words, which enabled the researchers to compare, contrast and analyse patterns within them. ${ }^{86}$ A strength of these qualitative data was the 'lived experience', appropriate for locating the meanings that these interviewees place on the events, processes and structures of their lives. ${ }^{87}$ The data supported the findings of previous research, ${ }^{88}$ where the ability of the children to connect these meanings to the social world around them was discussed.

\section{FOCUS GROUPS' INTERVIEW RESULTS AND DISCUSSION}

The findings were clustered into the five main themes, identified at the outset of the methodology.

\section{Influences}

The researchers attempted to establish whether parents, peer group and the advertising media were the main influencing factors on the sample. The research confirmed that parents and the subjects' peer group were indeed fundamental to the decision-making process. ${ }^{89}$ However, advertising media, other than teenage magazines, had little, if any, effect on the behaviour of the focus groups. These findings contrast with those of previous research, ${ }^{90}$ in which 'the two main influences were found to be friends and television'. The following statements from group members at the interview included, 'I recently bought a new pair of trousers and a top that I saw in one of the "cool" magazines'; 'I don't pay much attention to adverts — I don't think they always tell the truth'; 'I look at the adverts in my magazines to see what "cool" clothes the pop stars and so on are wearing, but that is usually as far as it goes'; 'I go shopping with my friends at the weekend and we talk about the fashion stories that we have read in our favourite magazines, including what the celebs, like Britney Spears and Posh Spice are wearing'; and 'We all swap our magazines so that we can see what is cool'. 
Parents

All the respondents stated that their mother was very influential in choosing the clothes bought for school and for special occasions. This extended to the cost of the item - where pocket money and their own savings would not cover the purchase price. In those circumstances, the norm appears to be that there is an expectation that the parent will pay. As far as seeking advice from parents is concerned, the respondents actively sought advice when the variables of quality, price and special occasion were at stake, and acknowledged that their parents were more experienced in this situation than they were: 'I'd ask my mum and dad, if I was buying a new outfit for say a wedding, because it will be expensive and you want to make sure that the clothes are good quality'.

\section{Peer group}

When the girls buy their own casual or fashion wear, they realise that people suit different types of clothing and that each has their own style: 'My best friend is really tall and she can wear clothes that don't look "cool" on me. She knows what suits me and so do I'; (cross-section of interviewees' remarks). They make a conscious decision regarding the clothes they wear, however, depending on which friends they are with and on where they are going. Once they have left their friends, they reflect on the comments made about their choice of clothes, when worn on that occasion: 'Susan really liked the Calvin Klein top and trousers I wore at the party and said I should wear it when we go out next time' and 'I was annoyed when the girls told me that the style looked really sad'. Older sisters' opinions were valued, and the advice given by them was heeded: 'My sister works in Gap at the weekend and she tells me about all the good new stuff that has come in'.

\section{Media}

The interviewees were asked about the influence of the advertising media on their buying behaviour, and no mention was made of radio; they could not recollect any current advertising campaign; only passing reference was made to television. In general, the only medium of any significance to this target group was teenage magazines and the fashion articles and fashion advertisements which appeared in them.

\section{Buying behaviour}

The respondents were extremely confident in their own ability to assess what clothes they should/should not buy, and articulated clearly that they liked and enjoyed making their own decisions on what clothes they would wear, demonstrating their individual behaviour. ${ }^{91}$ The approval of friends, while important, did not override the fact that they were their own person, had their own identity: 'I know best what suits me'; 'I buy what I like'; and 'I buy clothes because I like them or sometimes because my friends really like them and I like them as well'. The store's own branding activities, vis-à-vis its own products, has a bearing on their behaviour: 'I think the store and name sometimes influences me, but I don't want to be seen wearing the same clothes as my nine-year-old sister' (a selection of remarks by respondents).

\section{Information search}

An important source of information for these young people was older sisters, whom they respected and whose opinions they valued. In addition, use was made of teenage magazines, where the fashion columns were read closely and note taken of personalities/celebrities wearing particular clothes. 
The school environment is a source of information, in that, as part of the curriculum, the respondents are made aware of clothes being manufactured from all parts of the world, often by people working in adverse conditions, compared with those in the domestic market. This information had no bearing on their buying behaviour, however: 'No - not when I am buying the clothes' and 'No - I don't really think about it'.

\section{Brand awareness}

The concept of branding was clearly understood, and, unprompted, the respondents gave examples of well known clothing brands and the stores, where they could be purchased. 'I go to Gap, Top Shop and Miss Selfridge' and 'There are some brands of clothes that I do not like, but my favourite brand is Calvin Klein, who makes clothes that make me feel good in'. Of paramount importance to this group was obtaining the brand, irrespective of the outlet - it did not matter whether the clothing was bought in the brand's own outlet, a department store or even a supermarket, as long as the brand was available: 'I don't mind going to Debenhams because they have a good selection of brands that I like to wear all in one place'; 'I am happy to buy my clothes in a department store'; and 'It is all the same brand of clothing, it doesn't really matter where you buy the clothes from. In a department store or a clothes store, so long as it's nice'. It was accepted that the price is invariably higher in the brand's own outlet, and that the same item could be purchased at a lower cost, but price was of secondary importance to availability. This contradicts the Child Wise Insights findings that 'girls will hunt for "cheaper" versions of the "right" designer clothes'. As long as the brand continued to provide satisfaction, they would continue to be loyal to that brand.
However, they were prepared to switch to other brands which reflect their changing tastes, preferences and stage of development. ${ }^{92}$

What these respondents are seeking from a brand is visibility: 'modern clothes that you feel good in'; a brand that provides choice in the range; attractiveness; modernity; fashionability, 'coolness' and 'something to be recognised in'. This is reflected in the statements - 'If you pay a ridiculous price then you want people to see the label'; 'If it is a well known one, then you are wanting people to know that you are wearing it'; and 'Something you look good in - really cool, sophisticated and modern, but not too in your face' (cross-section of interviewees' remarks).

When the item of clothing is concealed by outer or over clothing, respondents deemed it to be quite permissible to buy and wear an unbranded product: 'If it is just a plain white $\mathrm{T}$ shirt, then you really don't need to buy a really expensive one, if you can buy a much cheaper one, because my friends are not going to see it anyway'. The respondents are therefore, in effect, seeking an augmented product, ${ }^{93}$ which comprises 'additional consumer services and benefits built around the core and actual products'. Such a product will give them 'bundles of benefits' that satisfy their needs.

\section{Expectations of the brand}

Sometimes the search criteria are not always satisfied and respondents said that they would look for alternatives, when their preferred brand failed to meet their buying requirements, in terms of providing them with a wide choice. The respondents, however, expected a consistently high quality from branded clothing products. Expectations were not always matched, however, and several 
Table 3: The reflective stage in the consumer socialisation process

\begin{tabular}{|c|c|c|}
\hline Topic & $\begin{array}{l}\text { Reflective stage } \\
\text { (11-16 years) }\end{array}$ & $\begin{array}{l}\text { Findings on the themes from research } \\
\text { undertaken }\end{array}$ \\
\hline Advertising knowledge & Sceptical attitudes towards & $\begin{array}{l}\text { (1) Aware, but not significant influence of } \\
\text { advertisements. However, parental and peer } \\
\text { group influence is considerable. }\end{array}$ \\
\hline Decision strategies & $\begin{array}{l}\text { Use of multiple attributes } \\
\text { Full repertoire of strategies }\end{array}$ & $\begin{array}{l}\text { (2) Wide variety of personal and non-personal } \\
\text { sources used in decision making. } \\
\text { Negotiation strategies employed when deemed } \\
\text { appropriate for individuals' self-interest. }\end{array}$ \\
\hline Information search & $\begin{array}{l}\text { Gather information on } \\
\text { functional perceptual and } \\
\text { social aspects }\end{array}$ & $\begin{array}{l}\text { (3) Extensive searching undertaken, but the } \\
\text { social aspect (eg working conditions) has no } \\
\text { impact. }\end{array}$ \\
\hline $\begin{array}{l}\text { Product and brand } \\
\text { knowledge }\end{array}$ & $\begin{array}{l}\text { Substantial brand awareness } \\
\text { for adult-oriented as well as } \\
\text { child-relevant product } \\
\text { categories } \\
\text { Understanding and enthusiasm } \\
\text { for retail stores }\end{array}$ & $\begin{array}{l}\text { (4) Highly aware of full brand range and of } \\
\text { individual brands. } \\
\text { Extremely knowledgeable and enthusiastic about } \\
\text { range of stores available. }\end{array}$ \\
\hline Product evaluation & $\begin{array}{l}\text { Focus on important attribute } \\
\text { information: functional, } \\
\text { perceptual and social aspects }\end{array}$ & $\begin{array}{l}\text { (5) Thorough evaluations undertaken, with } \\
\text { functional, perceptual and social aspects critical, } \\
\text { when buying fashion clothing. }\end{array}$ \\
\hline
\end{tabular}

Source: Adapted from John (1999) ${ }^{36}$

bad experiences were relayed. 'I once bought a really expensive designer top and it basically fell apart and it was awful. But it has not stopped me buying that label again. It was disappointing because of the money my Mum had paid for it' and 'I bought a pair of expensive trousers and the zip broke a week after, which was a bit annoying, but like Susan, I've bought that label again'.

\section{CONCLUSIONS}

The researchers ascertained that the purchasing of fashion items is strongly influenced by the brand name and its associations. The influence of branded products operates at both a conscious and subconscious level. ${ }^{94}$ The respondents are prepared to pay a premium price for a branded product and place much emphasis on the fact that the product is deemed as 'cool' and is respected by their peer group. In addition, the respondents' brand awareness directed them to those retail outlets where the branded goods were readily available. They did not shop around to any great extent, as in most instances they had a clear idea of what they wished to buy. When a special occasion demanded, however, the decision-making process was more complex, and they were also prepared to pay more for the item and seek the approval of their parents.

Key findings which emerged from the pre-selected themes included the fact that these tweenage girls placed a high value on branded clothes, design and style, and knew the brands that suited them. In addition, they both expected and demanded that the clothing they buy and wear reflect their personality and self-image. They insisted that they are the final arbiters as far as fashion and casual wear clothing for them is concerned. It is interesting to note that, in spite of the fact that the girls attended one state school and one private school, the findings showed no discernible cultural or societal background differences in their attitudes, buying behaviour, brand awareness or brand preferences.

Retailers targeting this particular segment would need to provide a range of branded goods that were positioned as good quality, fashionable and deemed 
'cool'. Table $3^{95}$ summarises the reflective stage in the consumer socialisation process, comparing it with the main findings to emerge from the qualitative research undertaken. The five themes were developed to link in with the topics of John's model, in an attempt to add to the extant body of knowledge in general, and to the reflective stage, represented by the interviewees, in particular. Since this study was exploratory and limited to a number of tweenage girls, findings can only be used as a guide for further research into this area. The purpose of the next stage in the research is to extend it to older female teenagers and their parents from the same sample area.

\section{References}

1 Lindstrom, M. (2003) 'Junior consumer', Marketing Business, March, pp. 26-27.

2 BBC News (2000) 'Tweenagers rule the High Street'. Available from: http://www.news.bbc.co.uk/ 1/hi/business/882606.stm [Accessed: 10th May, 2003].

3 Mintel International Group Limited (2001) 'Childrenswear retailing,' December. Available from: http://reports.mintel.com [Accessed 28th March, 2003].

4 Clarke, B. (2003) 'The angst, anguish and ambitions of the teenage years', International Journal of Advertising and Marketing to Children, Vol. 4, No. 3, pp. 27-33.

5 Levinson, L. (2001) in Capowski, W. 'Girl gear', Supermarket Business, Vol. 56, No. 1, pp. 49-50.

6 Cioletti, J. (2001) 'The tween scene', Supermarket Business, Vol. 56, No. 5, pp. 33-34.

7 Strong, C. (1998) 'The impact of environmental education on children's knowledge and awareness of environmental concerns', Marketing Intelligence and Planning, Vol. 16, No. 6, pp. 349-355.

8 Anon (2001) 'Tweenagers under the influence', Brand Strategy, No. 152, pp. 24-25.

9 Moschis, G. (1985) 'The role of family communication in consumer socialization of children and adolescents', Journal of Consumer Research, Vol. 11, pp. 898-913.

10 BBC News (2000) op. cit.

11 Dwek, R. (1998) 'Child's play?' Marketing Business, September, pp. 12-15.

12 GMTV - Out of pocket? (2001) Available from: http://www.gmtv.co.uk/index.cfm?articleid= 4862\&ArticleAction=print [Accessed 8th April, 2003].

13 Child Wise Insights (2001) 'Children's purchasing habits' available from http://www.childwise.co.uk/ purchasing.htm [Accessed 14th April, 2003].

14 Mintel (2001) op. cit.

15 Mintel (2002) 'Market Intelligence Series, Pocket

Money — Non Food and Drink - UK Report',

August. Available from: http://www.

marketresearch.com $/$ search $/$ results.asp?SID =

79811281-330386044-393255085\&qtype $=$

$1 \&$ query $=$ total + annual + spending + power + for + uk +

children $+7+\% 2 \mathrm{D}+16+$ year+olds\&categoryid $=$

80\&regionid $=0 \&$ mcats $=$ Apparel $\% 20$ Retailing

[Accessed: 25th August, 2002].

16 'Wall's 27th Annual Pocket Money Monitor' (2001) available from: http://www.

teachersupport.org.uk/printpage.cfm?p=938 [Accessed 4th March, 2003].

17 Child Wise Insights (2003) op. cit.

18 Mintel (2001) op. cit.

19 Datamonitor (2002) 'Tweenagers report'. Available from: http://news.bbc.co.uk/1/hi/business/ 882606.stm [Accessed: 17th June, 2003].

20 Pattullo, E. (ed.) (2002) Key Note Childrenswear Market Report, 4th edn, key Note, Hampton.

21 Ibid.

22 Ibid.

23 Mintel (2001) op. cit.

24 Jobber, D. (2001) 'Principles and Practice of Marketing', 3rd edn, McGraw-Hill, London, UK.

25 Kotler, P. Armstrong, G., Saunders, J. and Wong, P. (2001) 'Principles of Marketing', Prentice Hall, Englewood Cliffs, NJ.

26 Lamb, C., Hair, J. and McDaniel, C. (2002) 'Marketing', Southwestern Publishing, Cincinnati, $\mathrm{OH}$.

27 Stokes, D. (2002) 'Marketing', Continuum, London.

28 Caruana, S. and Vassallo, R. (2003) 'Children's perception of their influence over purchases: The role of parental communication patterns', Journal of Consumer Marketing, Vol. 20 No 1, pp. 55-66.

29 North, E. and Kotz, T. (2001) 'Parents and television advertisements as consumer socialisation agents for adolescents: An exploratory study', Journal of Family Ecology and Consumer Sciences, Vol. 29, pp. 91-99.

30 Antonides, G. and van Raaij, F. W. (1998) 'Consumer Behaviour, A European Perspective', Wiley, Chichester.

31 Lawrence, D. (2003) 'The role of characters in kids marketing', International Journal of Advertising and Marketing to Children, Vol. 4, No. 3, pp. 44-48.

32 Baumrind, D. (1980) 'New directions in socialization research', American Psychologist, Vol. 35 (July), pp. 639-652.

33 Ward, S. (1974) 'Consumer socialization', Journal of Consumer Research, Vol. 1, pp. 1-14.

34 Wackmann, D. and Wartella, E. (1977) 'How Children Learn to Buy', Sage, London, UK.

35 Clarke (2003) op. cit.

36 John, D. (1999) 'Consumer socialization of children: A retrospective look at twenty-five years of research', Journal of Consumer Research, Vol. 26, pp. 183-213. 
37 Ibid.

38 Ward (1974) op. cit.

39 McNeal, J. (1973) 'An Introduction to Consumer Behaviour', Wiley, New York, NY.

40 McGregor, S. (1999) 'Socializing consumers in a global marketplace', Journal of Consumer Studies and Home Economics, Vol. 23, No. 1, pp. 37-45.

41 Piaget (1966) 'Piaget's Theory of Cognitive Development'. Available from: http://chiron. valdosta.edu/whuitt/col/cogsys/piaget.html [Accessed: 17th March, 2003].

42 Atherton, J. (2002) 'Learning and teaching: Piaget's developmental psychology'. Available from: http://www.dmu.ac.uk/ jamesa/learning/piaget.htm [Accessed: 17th March, 2003].

43 John (1999) op. cit.

44 Ibid.

45 Ibid.

46 North and Kotzé (2001) op. cit.

47 Acuff, D. S. (1997) 'What Kids Buy and Why: The Psychology of Marketing to Kids', Free Press, New York.

48 Doyle, P. (1993) 'Building successful brands: The strategic options', Journal of Consumer Marketing, Vol. 2, pp. 5-20.

49 Anon (2002) 'About brands'. Available from: http://www.dobney.com/Strategies/brands.htm [Accessed: 17th April, 2003].

50 Ibid.

51 Ibid

52 Macrae, C. (1996) 'The Brand Chartering Book', Addison-Wesley, London.

53 Lindstrom (2003) op. cit.

54 Ibid.

55 Bandura, A. (1977) 'Social Learning Theory', Prentice-Hall, Englewood Cliffs, NJ.

56 Martin, C. and Bush, A. (2000) 'Do role models influence teenagers' purchase intentions and behavior?', Journal of Consumer Marketing, Vol. 17, No. 5, pp. 441-454.

57 Ibid.

58 Ibid.

59 Ibid.

60 Ibid.

61 Easterby-Smith, M., Thorpe, R. and Lowe, A. (2002) 'Management Research,' 2nd edn, Sage, London, UK.

62 Holsti, O. (1969) 'Content Analysis for the Social Sciences and Humanities', Addison-Wesley, Reading, MA.

63 Fontana, A. and Frey, J. (1994) 'Interviewing: The Art of Science' in Denzin, N. and Lincoln, Y. (eds), 'Handbook of Qualitative Research', Sage, Beverly Hills, CA.

64 John (1999) op. cit.

65 Saunders, M., Lewis, P. and Thornhill, A. (1977) 'Research Methods for Business Students', Pitman Publishing, London, UK.

66 Morgan, D. (1990) 'Focus Groups as Qualitative Research', Sage Publications, Newbury Park, CA.

67 Threlfall, K. (1999) 'Using focus groups as a consumer research tool', Journal of Marketing Practice:
Applied Marketing Science, Vol. 5 No 4, pp. 102-105.

68 Madriz, E. I. (1998) 'Using focus groups with lower socioeconomic status Latina women', Quality Inquiry, Vol. 24, No. 1, pp. 114-128.

69 Yates, S. J. (2003) 'Doing Social Science Research'. London, Sage, in association with The Open University.

70 Easterby-Smith (2002) op. cit.

71 Creswell, J. (2003) 'Research Design: Qualitative, Quantitative and Mixed Methods Approaches', Sage, London.

72 Rubin, H. and Rubin, I. (1995) 'Qualitative Interviewing: The Art of Hearing Data', Sage, Thousand Oaks, CA.

73 Creswell (2003) op. cit.

74 Mertens, D. (2003) 'Research Methods in Education and Psychology: Integrating Diversity with Quantitative and Qualitative Approaches', Thousand Oaks, Sage, CA.

75 Rapoport, A. (1969) 'Operational Philosophy', Wiley, New York, NY.

76 Nachmias, D. and Nachmias, C. (1996) 'Research Methods in the Social Sciences', 5th edn, Arnold, London.

77 Yin, R. K. (1984) 'Case Study Research: Design and Methods', 2nd edn; Applied Social Research Methods Series, Vol. 5. Sage, Beverley Hills, CA.

78 Glaser, B. (1978) 'Theoretical Sensitivity', Sociology Press, Mill Valley, CA.

79 Gill, J. and Johnson, P. (1991) 'Research Methods for Managers', Paul Chapman Publishing, London.

80 Glaser, B. and Strauss, A. (1967) 'The Discovery of Grounded Theory: Strategies for Qualitative Research', Aldine, New York, NY.

81 Miles, N. and Huberman, A. (1994) 'An Expanded Sourcebook, Qualitative Data Analysis', 2nd edn, Sage, London.

82 Silverman, D. (1985) 'Qualitative Methods in Sociology', Gower, London.

83 McDonagh, P. (2002) 'Communicative campaigns to effect anti-slavery and fair trade: The cases of Rugmark and Cafedirect', European Journal of Marketing, Vol. 36, No. 5/6, pp. 642-666.

84 Bryman, A. (1998) 'Quantity and Quality in Social Research', Routledge, London.

85 McDonagh (2002) op. cit.

86 Miles and Huberman (1994) op. cit.

87 Ibid.

88 van Manen, M. (1977) 'Linking ways of knowing with ways of being practical', Curriculum Inquiry, Vol. 6, No. 3, pp. 205-228.

89 Caruana and Vassallo (2003) op. cit.

90 Anon (2001) op. cit.

91 Brooks, I. (2003) 'Organisational Behaviour: Individuals, Groups and Organisation', 2nd edn, Financial Times, Prentice Hall, Harlow, UK.

92 Rossiter, J. and Percy, L. (1987) 'Advertising and Promotion Management', McGraw-Hill, New York, NY.

93 Kotler (2001) op. cit.

94 Ibid.

95 John (1999) op. cit. 